\title{
ROLA PAŃSTWA W KONSTYTUOWANIU SIĘ KOŚCIOŁA PRAWOSŁAWNEGO UKRAINY W KONTEKŚCIE WYZWAŃ BEZPIECZEŃSTWA NARODOWEGO
}

\author{
THE ROLE OF THE STATE IN THE CONSTITUTION \\ OF THE ORTHODOX CHURCH OF UKRAINE IN THE CONTEXT \\ OF NATIONAL SECURITY CHALLENGES
}

Antonina Kozyrska*

\begin{abstract}
ABSTRAKT
Artykuł prezentuje rolę państwa ukraińskiego w procesie tworzenia Kościoła Prawosławnego Ukrainy i uzyskania przez niego autokefalii w kontekście wyzwań bezpieczeństwa narodowego Ukrainy po Rewolucji Godności. Badania zostały oparte na literaturze naukowej, materiałach proweniencji państwowej i kościelnej, oraz danych analitycznych i socjologicznych. Ich wyniki wskazują, że ukonstytuowanie się autokefalicznego Kościoła na przełomie 2018/2019 r. $\mathrm{w}$ dużej mierze było możliwe dzięki determinacji porewolucyjnego obozu władzy i uzyskaniu konsensusu politycznego sił prozachodnich ze względu na zagrożenia dla bezpieczeństwa państwa, co znalazło poparcie w społeczeństwie ukraińskim. Rozwój młodego Kościoła i utrwa-
\end{abstract}

\begin{abstract}
The article presents the role of the Ukrainian state in the process of creating the Orthodox Church of Ukraine and achieving autocephaly in the context of Ukraine's national security challenges after the Revolution of Dignity. The research was carried out on the basis of scientific sources, materials of state and church provenance, as well as analytical and sociological data. The results of research indicate that the formation of an autocephalous Church at the turn of 2018/2019 was largely possible due to the determination of the post-revolutionary ruling camp and obtaining a political consensus of pro-Western forces. That consensus could be achieved owing to the threats to state security, which was recognized and supported by Ukrainian society. The development
\end{abstract}

* Uniwersytet Mikołaja Kopernika w Toruniu, Wydział Nauk o Polityce i Bezpieczeństwie. 
lenie autokefalii wymaga dalszego wsparcia ze strony organów władzy.

Słowa kluczowe: Rewolucja Godności; konflikty religijne; Prawosławny Kościół Ukrainy; bezpieczeństwo narodowe Ukrainy; konflikt ukraińsko-rosyjski of the young Church and the consolidation of autocephaly requires further support from the authorities.

Keywords: Revolution of Dignity; religious conflicts; Orthodox Church of Ukraine; national security of Ukraine; Ukrainian-Russian conflict

\section{WPROWADZENIE}

Rewolucja Godności z przełomu lat 2013-2014 i jej skutki oraz rosyjska agresja stały się impulsem do rewizji priorytetów w zakresie polityki zagranicznej oraz bezpieczeństwa narodowego Ukrainy. Skupiły się one teraz na prozachodnim kierunku polityki, obronie suwerenności i integralności terytorialnej Ukrainy, wzmocnieniu jej potencjału obronnego, ale też na przeciwdziałaniu zagrożeniom niemilitarnym płynącym przede wszystkim z Rosji, obronie międzynarodowego prestiżu państwa, wzmocnieniu ogólnonarodowej tożsamości Ukraińców. Potrzeba konsolidacji społeczeństwa w obliczu zagrożenia zewnętrznego uaktualniła problem podziałów w prawosławiu na Ukrainie i dążeń do niezależności kościelnej od Moskwy poprzez autokefalię.

Celem poniższych rozważań jest ukazanie roli państwa ukraińskiego (jego organów władzy, instytucji, partii politycznych i poszczególnych polityków) w procesie tworzenia Kościoła Prawosławnego Ukrainy (ukr. Православна Церква Украӥни - PCU) i uzyskania przez niego autokefalii w kontekście wyzwań bezpieczeństwa narodowego Ukrainy po Euromajdanie. Omówione zostaną uwarunkowania, motywacja polityczna, główne etapy procesu, jego implikacje polityczne i społeczna percepcja na Ukrainie. Główna hipoteza badawcza brzmi: ukonstytuowanie się PCU jako autokefalicznego Kościoła na przełomie 2018/2019 r. w dużej mierze było możliwe dzięki determinacji porewolucyjnego obozu władzy i uzyskaniu konsensusu politycznego sił prozachodnich ze względu na zagrożenia dla bezpieczeństwa państwa, co znajdowało poparcie w społeczeństwie ukraińskim. Zastosowane w pracy metody i techniki badawcze to przede wszystkim analiza treści oraz źródeł, metoda obserwacji i behawioralna. Wielowymiarowość problematyki sprawia, że należy ją badać w sposób interdyscyplinarny, uwzględniając perspektywę religioznawczą (aspekt eklezjalny), historyczną (proces dziejowy), jak też nauk o polityce (np. wpływ na procesy polityczne) i nauk o bezpieczeństwie (kontekst aktualnych zagrożeń, 
wojny informacyjnej). W tym ostatnim przypadku w literaturze przedmiotu od niedawna występuje pojęcie bezpieczeństwa religijnego lub wyznaniowego (Harbatski, 2015; Relihiyna, 2019). Niniejsze opracowanie stanowi próbę połączenia wymienionych aspektów.

\section{UWARUNKOWANIA UKRAIŃSKICH STARAŃ O AUTOKEFALIĘ}

Początki dyskusji na temat autokefalii Kościoła prawosławnego we współczesnej Ukrainie sięgają okresu kształtowania się państwowości ukraińskiej pod koniec XX w. Prawosławie tu jest największym wyznaniem pod względem liczby wiernych ${ }^{1}$ i wielkości struktury administracyjno-terytorialnej, lecz od strony instytucjonalnej nie stanowi monolitu. W latach 90. ubiegłego wieku ugruntował się podział na trzy główne grupy kościelne (jurysdykcje). Każda z nich miała własną wizję zależności od zewnętrznych struktur kościelnych, roli w życiu państwa i narodu, języka używanego w nabożeństwach itp. Przekładało się to na rywalizację o wpływy wśród wiernych, o świątynie i względy państwa. Najbardziej rozbudowaną strukturę posiadał Ukraiński Kościół Prawosławny (UPC), który wcześniej należał do Rosyjskiego Kościoła Prawosławnego (RPC), a w 1990 r. uzyskał autonomię w ramach Patriarchatu Moskiewskiego (PM). $\mathrm{Na}$ jego czele od 2014 stoi metropolita kijowski i całej Ukrainy, Onufry. Drugą pozycję zajmował Ukraiński Kościół Prawosławny - Patriarchat Kijowski (UPC KP), który powstał w 1992 r. w wyniku rozłamu w UPC. W odróżnieniu od tej ostatniej wspólnota ta nie podlegała Moskwie, miała proukraińską orientację, ale nie była uznawana przez światowe prawosławie. Jej zwierzchnikiem od $1995 \mathrm{r}$. był patriarcha kijowski i całej Ukrainy Filaret. Najmniejszym był Ukraiński Autokefaliczny Kościół Prawosławny (UAPC) - również niekanoniczna wspólnota, restytuowana na Ukrainie w 1990 r., geneza której sięga ukraińskich tradycji niepodległościowych z początku XX w. Na początku 2013 r. UPC liczyła 12574 parafii, UPC KP - 4563, UAPC - 1205 (zob. Kozyrska, 2014, ss. 165-237).

Biorąc pod uwagę przynależność osób do wspólnot kościelnych, według sondażu Centrum Razumkowa z marca 2013 r., przewaga UPC (28\%) była już

1 Dysponujemy jedynie danymi szacunkowymi, a ich źródłem są badania socjologiczne. W świetle sondaży w pierwszej dekadzie XXI w. liczba osób utożsamiających się ogólnie z tradycją prawosławną wahała się w granicach 70\%. W tej grupie wysoki odsetek respondentów nie identyfikował się z konkretnym Kościołem - tzw. „po prostu prawosławni” (39\% w 2000 r., 26\% w 2010 r., 41\% w 2013 r.) (Kozyrska 2014, 181-182). 
niewielka względem UPC KP (26\%), zaś z UAPC utożsamiało się nieco ponad $1 \%$ ankietowanych (Oleksiyenko, 2014). Na tej podstawie można przyjąć, że w przededniu Euromajdanu zwolenników autokefalii, należących do UPC KP i UAPC oraz przychylnych idei w UPC, było prawie tylu, co jej przeciwników. Nie można jednak stwierdzić, że koncepcja cieszyła się powszechnym uznaniem społeczeństwa, zważając na wysoki wskaźnik kategorii osób „po prostu prawosławnych” (41\%), których nie interesowały spory kościelne.

Zwolennicy autokefalii byli świadomi, że podziały w prawosławiu stanowiły przeszkodę w urzeczywistnieniu tych dążeń. Podejmowane próby zjednoczeniowe przez prawie ćwierćwiecze nie dawały pożądanych efektów. Wpływ na to miały m.in. różnice poglądów Kościołów prawosławnych na Ukrainie na temat sposobów przywrócenia jedności, samej zasadności starań o autokefalię, osobiste ambicje zwierzchników poszczególnych Kościołów. UPC nie zamierzała zrywać więzi kanonicznej z Moskwą, uważając, że to pozostałe Kościoły jako schizmatyckie mają powrócić na jej łono. Z kolei UPC KP widziała siebie jako jądro zjednoczonego Kościoła i w oparciu o doświadczenie historyczne innych Kościołów autokefalicznych wierzyła, że z czasem uzyska kanoniczne uznanie. W środowisku tego Kościoła panowało przekonanie, że państwo powinno wspierać jego dążenia, gdyż działał na rzecz wzmocnienia tożsamości narodowej i państwowości ukraińskiej, i niejako „unaradawiał” miejscowe prawosławie. Także w UAPC istniało przeświadczenie, że tylko ona była rdzennym Kościołem ukraińskim i jedyną sukcesorką Kościoła Rusi Kijowskiej, jednak mniejszą rolę przypisywano wsparciu ze strony władz państwowych (Trojanczuk, 2012, ss. 212-217).

Przeciwnicy ukraińskiej autokefalii podkreślali, że powinna ona być uzasadniona motywami religijnymi, a nie politycznymi. PM nie godził się na pomniejszenie swego terytorium kanonicznego. Tymczasem sama RPC po 1991 r. pozostawała „integralną częścią struktury państwowej Rosji”, z którą ją łączyła wspólnota interesów (Mironowicz 2007, s. 43). Dotyczyło to także polityki dominacji na obszarze poradzieckim. Sojusz obu podmiotów wzmocnił się dzięki bliskim relacjom prezydenta W. Putina i patriarchy Cyryla. RPC propagowała idee rosyjskiej cywilizacji prawosławnej, „Świętej Rusi”, jako ważnego elementu „rosyjskiego świata”. Patriarcha moskiewski aktywnie je lansował, m.in. w czasie podróży pasterskich na Ukrainę.

Kolejną barierę dla ukraińskich aspiracji stanowiła powściągliwa pozycja Patriarchatu Konstantynopolitańskiego, który unikał konfliktu z PM. Obie struktury rywalizowały ze sobą o faktyczne przywództwo w świecie prawosławnym. 
Nie było też zgodności co do procedury otrzymania autokefalii, miał ją określić długo oczekiwany Sobór Wszechprawosławny.

Specyfika ustroju Kościoła prawosławnego i modelu stosunków z państwem, doświadczenie dziejowe, $\mathrm{w}$ tym ukraińskie $\mathrm{z}$ lat 90. XX w., wskazują na łączenie religijnego aspektu autokefalii z politycznym. Pierwotnie środowiska kościelne, polityczne i inteligenckie, popierające ideę autokefalii na Ukrainie, uzasadniały ją potrzebą wzmocnienia procesów państwowotwórczych. Autokefaliczny Kościół lokalny miał być jednym $\mathrm{z}$ atrybutów niepodległego państwa. Hasło „W niepodległym państwie niezależny Kościół” lansował m.in. pierwszy prezydent Ukrainy L. Krawczuk. Stosunek kolejnych głów państwa, rządów, parlamentarzystów do omawianej kwestii zależał m.in. od ich sposobu rozumienia ukraińskiej idei narodowej, geostrategicznych interesów państwa, wizji stosunków rosyjsko-ukraińskich. Idea powstania Kościoła prawosławnego, jako wspólnoty wyznaniowej łączącej na płaszczyźnie wspólnych wartości, tradycji i instytucji dominującą większość Ukraińców, zyskała uznanie ze strony prezydentów L. Krawczuka i W. Juszczenki, lecz zupełnie nie interesowała W. Janukowycza, który w polityce zagranicznej preferował wzmocnienie relacji z Federacją Rosyjską, a w polityce wyznaniowej faworyzował UPC (Kozyrska 2014, ss. 319-339).

Biorąc pod uwage powyższe uwarunkowania, prognozy co do realizacji koncepcji autokefalii ukraińskiej w perspektywie krótkoterminowej były raczej pesymistyczne. Sytuacja niespodziewanie uległa zmianie po Rewolucji Godności.

\section{NOWE TENDENCJE W ŚRODOWISKU PRAWOSŁAWNYM I DIAGNOZA ZAGROŻEŃ}

Wraz z wybuchem Euromajdanu w środowisku prawosławnym zarysowały się nowe tendencje. Szczególnie po aneksji Krymu przez Rosję i jej zaangażowaniu w konflikt w Donbasie na Ukrainie pojawiły się mocniejsze polityczne i ideologiczne podstawy dążeń do niezależności kościelnej od RPC, ściśle związanej z Kremlem. Gwałtowany wzrost antyrosyjskich nastrojów w społeczeństwie w tym przypadku stanowił sprzyjającą okoliczność. Stosunek duchowieństwa poszczególnych Kościołów do bieżących procesów społeczno-politycznych na Ukrainie przekładał się na ich popularność w społeczeństwie. Proporcje poparcia dwóch największych Kościołów w perspektywie niecałej dekady odwróciły się. W świetle sondaży Centrum Razumkowa w okresie od 2010 do 2017 r. UPC straciła połowę swoich wyznawców (24\% a $12 \%)$. Tymczasem notowania UPC 
KP wrosły niemal dwukrotnie (z 15\% do 27\%), a patriarsze Filaretowi ufało więcej Ukraińców (36\%) niż metropolicie Onufremu z UPC (31\%). Największy spadek zaufania zanotowano w przypadku patriarchy moskiewskiego Cyryla (z 44\% do 15\%), któremu nie ufało najwięcej Ukraińców (42\%) (Razumkov Centre, 2017, ss. 24-40)2.

Spadkowi autorytetu UPC towarzyszył żywiołowy proces przechodzenia części jej wiernych do UPC KP. Na początku 2016 r. już ponad 50 parafii przyłączyło się do UPC KP, co generowało konflikty. Prorosyjska opozycja polityczna piętnowała incydenty, określając je napadami na świątynie UPC. Próby uregulowania procedury w tym zakresie od 2016 r. podejmowała Rada Najwyższa Ukrainy (RNU) (Kozyrska, 2018, ss. 20-22). PM starał się poruszyć opinię międzynarodową, informując o przymusowym przejmowaniu świątyń UPC, wywieraniu na nią presji przez ukraińskie władze centralne i samorządowe (NISS 2018, ss. 31-32). W Rosji zaczęły ukazywać się publikacje propagandowe alarmujące o prześladowaniach religijnych na Ukrainie (np. Mal'tsev, 2016).

UPC ignorowała dialog w kierunku zjednoczenia Kościołów, zainicjowany przez UPC KP i UAPC po Euromajdanie. Wynikał on nie tylko z motywów eklezjalnych (zakończenie schizmy), ale też z pobudek patriotycznych i dążeń do zjednoczenia narodu w obliczu licznych zagrożeń wewnętrznych i zewnętrznych. W tym ostatnim kontekście problem konsolidacji prawosławia na Ukrainie i jego niezależności od zagranicznych ośrodków decyzyjnych coraz częściej stawał się tematem debaty publicznej. Przed 2014 r. bowiem wątek ten był poruszany rzadko i prędzej w dyskusji naukowej. Już wtedy uczeni dostrzegali zagrożenie w jurysdykcyjnej zależności od RPC największego Kościoła prawosławnego UPC, co warunkowało jego antyukraińską postawę. Stąd ukonstytuowanie się zjednoczonego autokefalicznego Kościoła prawosławnego było uznawane za jeden z priorytetowych celów rozwoju procesów religijnych na Ukrainie (Shapravs'kyy, 2010, ss. 169-173).

W dokumentach definiujących politykę państwa czynnik religijny w powiazaniu z kategorią bezpieczeństwa narodowego występował marginalnie i dotyczył głównie prewencji konfliktów wewnętrznych, ekstremizmu i separatyzmu na tle religijnym. Aspekt potrzeby tworzenia Kościoła niezależnego od Moskwy był pomijany. Nowa Strategia Bezpieczeństwa Narodowego z 2015 r. nie stanowiła pod tym względem wyjątku. Tematyka autokefalii nie należała do istotnych

2 Sondaże wykonane po 2014 r. nie były realizowane na terenie Krymu i niekontrolowanej przez rząd ukraiński części Donbasu. 
w kampanii prezydenckiej 2014 r. Postulat utworzenia zjednoczonego prawosławnego Kościoła lokalnego zawarł w swoim programie wyborczym tylko W. Kujbida - przewodniczący prawicowego Ludowego Ruchu Ukrainy, który osiągnął znikomy wynik wyborczy. W programach partii politycznych startujących w przyśpieszonych wyborach parlamentarnych 2014 r. temat nie był obecny. Nie odnosił się też do niego tekst umowy powołującej koalicję Europejska Ukraina.

Stopniowo zainteresowanie polityków obozu władzy problemem rosło. Prezydent P. Poroszenko w orędziach do RNU popularyzował koncepcję tworzenia niezależnego Kościoła lokalnego (Kozyrska, 2018, ss. 22-24). Zdaniem prezydenta naród ukraiński po ponad trzystu latach oczekiwań zasłużył na własny Kościół narodowy, który będzie zwieńczeniem procesu tworzenia suwerennego europejskiego państwa. Realizację tej koncepcji polityk ten uważał za jeden ze swych priorytetów, obok wzmocnienia armii i pozycji języka ukraińskiego (Poslannya, 2018).

Myśl polityczną głowy państwa rozwijały analizy Narodowego Instytutu Studiów Strategicznych przy Prezydencie Ukrainy (NISS). Jego eksperci uważali, że należało dążyć do neutralizacji sił antyukraińskich, w tym RPC, która instrumentalizowała UPC jako ważny kanał rosyjskiej propagandy na Ukrainie. UPC zarzucano ukrainofobię znacznej części kleru, szerzenie ideologii „rosyjskiego świata”, bierność pod pozorem neutralności wobec agresji Rosji na Krymie i w Donbasie, i wobec przejawów separatyzmu. Piętnowano też kolaborację niektórych duchownych z rebeliantami, nawoływanie do obalenia nowego rządu w Kijowie, wzniecanie nienawiści na tle religijnym, apele do Rosji o zajęcie Zakarpacia, działalność w rejonie konfliktu w Donbasie prorosyjskich ugrupowań quasi-cerkiewnych. Zwracano uwagę na pogorszenie się stanu tolerancji religijnej na okupowanym Krymie i niekontrolowanych przez rząd ukraiński obszarach Donbasu. Krytykowano retorykę RPC, sugerującą brak różnic między narodem rosyjskim a ukraińskim, oraz negującą udział Rosji w konflikcie w Donbasie. (Kozyrska, 2018, ss. 14-22). Wskazywano na udział RPC w wojnie informacyjnej przeciw Ukrainie, również poprzez dyskredytację Rewolucji Godności, wyłonionych w jej wyniku organów władzy, UPC KP. Z kolei UPC uznawano za poważny destabilizator sytuacji politycznej i katalizator napięć społecznych na Ukrainie. Postulowano odpowiedzialność karną za antypaństwową działalność duchownych UPC (NISS, 2018, ss. 29-32). Przykładem było nawoływanie przez biskupa pomocniczego diecezji czerniowiecko-bukowińskiej UPC Longina do bojkotowania mobilizacji do wojska ukraińskiego w ramach operacji antyterrorystycznej (ATO) na wschodzie kraju. 
Wywody specjalistów wspomnianej instytucji państwowej zmierzały do wykazania, że w obecnej sytuacji geopolitycznej istniało zapotrzebowanie społeczne na „unarodowione" wartości duchowe, instytucje i projekty wzmacniające państwowość i tożsamość ukraińską. Do takich właśnie zaliczono powstanie zjednoczonej autokefalicznej Cerkwi na Ukrainie. Przekonywano, że do realizacji tego projektu należało podchodzić nie jako do problemu stricte religijnego, historycznego czy kulturowego, lecz z perspektywy interesów bezpieczeństwa narodowego Ukrainy. Okoliczności jak nigdy dotąd sprzyjały urzeczywistnieniu koncepcji z uwagi na konsolidację i mobilizację Ukraińców, wzrost zainteresowania problemem autokefalii ze strony społeczeństwa i polityków ukraińskich, Patriarchatu Konstantynopolitańskiego, oraz osłabienie pozycji UPC. W świetle sondażu Centrum Razumkowa z listopada 2016 r. ponad 44\% badanych uznało potrzebę tworzenia jednego Kościoła lokalnego na Ukrainie ( $25 \%$ było przeciw, 31\% nie miało zdania) (NISS, 2017, ss. 309-313). W okresie 2010-2017 prawie trzykrotnie spadła liczba zwolenników pozostania UPC w składzie PM (z 22\% do $8 \%)$. Nawet w grupie wiernych tego Kościoła wskaźnik ten sięgał tylko 30\% (Razumkov Centre, 2017, s. 24).

Ideę Kościoła niezależnego od RPC popierało środowisko religioznawcze, które łączyło ją ze wzmocnieniem państwowości i międzynarodowej pozycji Ukrainy, oraz tożsamości i jedności narodu, redukcją zewnętrznego uzależnienia kraju od ośrodków zagranicznych (Relihiyna, 2019).

\section{REALIZACJA KONCEPCII UKRAIŃSKIEJ AUTOKEFALII}

Oprócz wzrostu świadomości zasadności funkcjonowania niezależnego Kościoła prawosławnego, istnienia w obozie „patriotycznym” woli politycznej w tym zakresie, kluczowym wyzwaniem było znalezienie podmiotu kościelnego, który pomógłby w zjednoczeniu Cerkwi ukraińskiej i wydał tomos (dekret kościelny) udzielający jej autokefalii. Przytoczone wyżej powody wykluczały kierowanie prośby do PM. Za odpowiedni podmiot został uznany Patriarchat Konstantynopolitański, który nie tylko honorowo przewodniczył prawosławiu światowemu, ale do końca XVII w. był Kościołem macierzystym Cerkwi kijowskiej. Jedynie połączenia wysiłków ukraińskich instytucji państwowych i kościelnych zwiększało szanse na powodzenie zamiarów.

Bardzo ważną rolę w skutecznej realizacji projektu odegrało osobiste zaangażowanie się prezydenta Poroszenki, choć po części wynikało to z jego kalkulacji 
politycznych. Przekonywał on polityków i spotykał się z przywódcami religijnymi na Ukrainie, ze zwierzchnikami autokefalicznych Kościołów prawosławnych. Pokłosiem jego wizyty u patriarchy ekumenicznego Bartłomieja I w marcu 2016 r. było to, że RNU wystosowała po raz pierwszy oficjalną prośbę w formie uchwały z 16 czerwca 2016 r. Deputowani prosili Bartłomieja I o wydanie tomosu o autokefalii dla Kościoła na Ukrainie jako spełniającego niezbędne warunki oraz o unieważnienie decyzji z 1686 r., w wyniku której metropolia kijowska stopniowo stawała się zależna od PM. Podkreślali też, że „współczesny Patriarchat Moskiewski zbyt ściśle jest związany z panującym w Rosji reżimem politycznym, by być odbierany właśnie jako Kościół, a nie «ministerstwo ideologii» Federacji Rosyjskiej" i współuczestniczy w wojnie hybrydowej przeciw Ukrainie (Postanova, 2016).

Strona ukraińska liczyła na szybkie rozpatrzenie jej wniosku z uwagi na rozpoczynający się za trzy dni na Krecie Sobór Wszechprawosławny. Nadzieje te okazały się płonne, gdyż RPC zbojkotowała zgromadzenie, a ojcowie soborowi z 10 Kościołów, którzy wzięli w nim udział, nie uzgodnili dokumentu o trybie ogłaszania autokefalii. Mimo że w trakcie wspomnianej wizyty prezydenta u patriarchy ekumenicznego ani późniejszej przewodniczącego parlamentu A. Parubija 19 listopada 2016 r. nie padła wprost obietnica wydania tomosu, to powyższe zachowanie PM, podważające pozycję Patriarchatu Konstantynopolitańskiego, mogło ostatecznie mieć wpływ na przyśpieszenie jego decyzji w kwestii ukraińskiej. Zjednoczony i kanoniczny Kościół na Ukrainie mógł stać się ważnym sojusznikiem Konstantynopola w rywalizacji z Moskwą (Kowalczyk, 2020, s. 10).

Do przełomu w sprawie tomosu doszło dopiero wiosną 2018 r. po ponownym spotkaniu prezydenta Poroszenki z patriarchą Bartłomiejem I i członkami Synodu Kościoła Konstantynopolitańskiego 9 kwietnia. 17 kwietnia prezydent spotkał się z liderami klubów parlamentarnych, prosząc o poparcie jego oficjalnego wniosku do patriarchy ekumenicznego o autokefalię. 19 kwietnia parlament wydał uchwałę popierającą petycję prezydenta (Postanova, 2018). Dzień wcześniej 40 biskupów UPC KP, 12 z UAPC i 10 z UPC podpisało apel o wydanie tomosu. 20 kwietnia zastępca szefa Administracji Prezydenta R. Pawłenko osobiście doręczył dokumenty Bartłomiejowi I. W trosce o jedność światowej wspólnoty prawosławnej patriarcha wysłał swoich delegatów do Kościołów autokefalicznych w celu zasięgnięcia ich opinii.

Wysiłki rządu ukraińskiego i hierarchów kościelnych wsparła wielomilionowa diaspora ukraińska, w tym Światowy Kongres Ukraińców. Jego przewodniczący 
J. Czolij także wcześniej dwukrotnie odwiedził Bartłomieja I (Svitovyy, 2018). Radość z powodu zapowiedzi rychłego przystąpienia do rozpatrywania wniosku wyraził episkopat Ukraińskiego Kościoła Stanów Zjednoczonych i Stałej Konferencji Ukraińskich Biskupów Prawosławnych poza Granicami Ukrainy (Sobor, 2018).

Z uwagi na fakt, że wciąż wysoki odsetek Ukraińców (ok. 41\%) był obojętny lub nie miał zdania w kwestii przyszłości prawosławia na Ukrainie (Razumkov Centre, 2017, s. 24) oraz w myśl wcześniejszych zaleceń ekspertów (NISS, 2017, s. 314), na Ukrainie ruszyła szeroka kampania informacyjna na rzecz tomosu. Zaangażowały się w nią resorty rządowe, instytucje państwowe, organizacje pozarządowe, media, naukowcy i politycy. Przykładowo Ministerstwo Kultury i Polityki Informacyjnej przygotowało szereg krótkich spotów, w których reprezentanci różnych środowisk (duchowni, weterani ATO, działacze kultury i nauki, wolontariusze itp.) lansowali hasło „Ukraińskiemu państwu ukraiński Kościół!” (MKIP, 2018). Na rzecz pozyskania opinii międzynarodowej działało Ministerstwo Spraw Zagranicznych. Dużo miejsca problemowi poświęcał 5 Kanał - prezydencka stacja telewizyjna.

W narracji historycznej towarzyszącej kampanii akcent kładziono m.in. na tym, że przed 1686 r. metropolia kijowska była samorządna, miała dobre warunki do kultywowania własnych tradycji i języka. Przyłączenie do RPC przerwało jej naturalny rozwój i oznaczało polityczną i religijną kolonizację Ukrainy, dlatego obecne dążenie do autokefalii to akt sprawiedliwości dziejowej. Eksponowana też była ciągłość historyczna tworzącego się właśnie Kościoła z UAPC z lat 1917-1921. Przeciwwagą narracji RPC o bratnich narodach czy wspólnej kulturze prawosławnej był przekaz o „duchowej okupacji”, ,aneksji” Kościoła ukraińskiego, „zawłaszczeniu” jego historii przez RPC, wytrąceniu go z europejskiej ścieżki rozwoju. Podobna narracja wyraźnie nawiązywała do obecnego konfliktu ukraińsko-rosyjskiego i adoptowała współczesną retorykę polityczną do procesów historycznych. Odzwierciedlała też antykolonialny dyskurs w ukraińskiej polityce historycznej z lat 2014-2019 (Fert, 2020).

PM aktywnie starał się blokować wysiłki Ukrainy za pośrednictwem kanałów dyplomatycznych i kościelnych, oraz prorosyjskich środowisk politycznych i religijnych na Ukrainie. W. Nowiński, oligarcha i poseł Bloku Opozycyjnego w RNU oraz aktywny obrońca UPC, wraz z kilkoma biskupami UPC, w czerwcu 2018 r. odwiedził patriarchę ekumenicznego. Ani ta wizyta, ani spotkanie obu patriarchów 31 sierpnia 2018 r. nie zdołały przekonać Bartłomieja I do wstrzymania decyzji w sprawie ukraińskiej autokefalii. 
Jesienią 2018 r. proces wkroczył w fazę kulminacyjną. Na Soborze Biskupów 1-2 września i w późniejszej ekspertyzie historycznej Patriarchat Konstantynopolitański wykazał, że PM przez wieki bezprawnie administrował metropolią kijowską. Bartłomiej I wydelegował na Ukrainę dwóch egzarchów, by we współpracy z władzami kościelnymi i cywilnymi przygotowali sobór zjednoczeniowy jako warunek wstępny wydania tomosu (Pravoslavna, 2021). Kluczowe znaczenie miały uchwały Synodu Patriarchatu Konstantynopolitańskiego z 9-11 października, który unieważnił decyzję z 1686 r. i orzekł, że metropolia kijowska nadal przebywa w jurysdykcji Kościoła Konstantynopolitańskiego. Synod wyraził zamiar wydania w najbliższym czasie tomosu o autokefalii Kościoła prawosławnego na Ukrainie. Środkiem przejściowym, który miał usprawnić proces konsolidacji ukraińskiego prawosławia, było uznanie kanoniczności UAPC i UPC KP, uchylenie kar kościelnych wobec ich zwierzchników i uznanie ważności sprawowanych w tych wspólnotach sakramentów (Olszański, 2018a, s. 1).

Mimo że P. Poroszenko zapewniał, że państwo będzie szanowało prawo każdego obywatela do wolności sumienia, to rząd przewidywał nasilenie konfliktów i prowokacje, dlatego starał się działać prewencyjnie. Minister spraw wewnętrznych A. Awakow zapowiedział zdecydowaną reakcję na takie sytuacje. Przykładem działań Służby Bezpieczeństwa Ukrainy w tym kierunku były rewizje w kilku diecezjach UPC, u opata Ławry Kijowsko-Peczerskiej, wezwania niektórych duchownych na przesłuchania czy brak pozwolenia metropolicie donieckiemu Ilarionowi na przekroczenie linii rozgraniczenia 9 grudnia $2018 \mathrm{r}$. UPC traktowała te incydenty jako formę presji ze strony państwa w celu nakłonienia jej do udziału w soborze zjednoczeniowym (Chervonenko, 2018).

Decyzje patriarchatu ekumenicznego wywołały krytyczne reakcje w Rosji. 12 października były przedmiotem posiedzenia Rady Bezpieczeństwa Federacji Rosyjskiej pod przewodnictwem W. Putina. Trzy dni później Synod RPC zerwał jedność z Konstantynopolem, zarzucając mu motywacje polityczne i pogłębianie podziału w prawosławiu na Ukrainie. W mediach rosyjskich episkopat patriarchatu ekumenicznego określano rozłamowcami, ulegającymi wpływom amerykańskim. W odpowiedzi minister spraw zagranicznych Ukrainy P. Klimkin schizmatykami nazwał RPC, a przewodniczący parlamentu A. Parubij oskarżył Kreml o inicjowanie konfliktu między Kościołami prawosławnymi (Strzelecki, 2018).

Rosyjska krytyka nie wstrzymała dalszych negocjacji Ukrainy z Konstantynopolem. 16 października 2018 r. wysłannicy Bartłomieja I spotkali się w Kijowie z prezydentem Ukrainy i przewodniczącym RNU. 3 listopada Poroszenko 
ponownie udał się z wizytą do Stambułu, gdzie omówił z patriarchą szczegóły co do organizacji soboru zjednoczeniowego i wydania tomosu. Strony podpisały umowę o współpracy, zawierającą zapis o uznaniu przez Ukrainę honorowego prymatu patriarchy ekumenicznego $\mathrm{w}$ świecie prawosławnym.

Zjednoczeniowy sobór lokalny odbył się już 15 grudnia 2018 r. w Kijowie, na którym został utworzony Kościół Prawosławny Ukrainy w miejsce rozwiązanych UPC KP i UAPC. Prawdopodobnie w zamian za ustępstwo niekandydowania przez patriarchę Filareta zwierzchnikiem PCU został wybrany jego protegowany Epifaniusz, $\mathrm{z}$ tytułem metropolity kijowskiego i całej Ukrainy (Olszański 2018b, s. 3). Najpewniej presja ze strony władz RPC i UPC wpłynęła na to, że na sobór przybyło tylko dwóch hierarchów UPC (Kowalczyk, 2020, s. 8). Oprócz episkopatu w zgromadzeniu wzięli udział przedstawiciele kleru niższego i wiernych, i jako gość prezydent Poroszenko. Zatwierdzony przez sobór statut PCU wchodził w życie po otrzymaniu tomosu. Nowy zjednoczony Kościół miał rangę metropolii, choć większość Ukraińców liczyła, że będzie to od razu patriarchat. Mimo opinii, że podniesienie PCU do rangi patriarchatu będzie kolejnym naturalnym etapem jej rozwoju eklezjalnego, w perspektywie krótkoterminowej taki scenariusz wydaje się mało realistyczny (Olszański 2018b, 2). Uchwały soboru już wieczorem uznał Patriarchat Konstantynopolitański. UPC nie zaakceptowała decyzji soboru, a swoich biskupów biorących udział w zgromadzeniu pozbawiła władzy w diecezjach (Zvernennya, 2018). Niższy kler, który poparł PCU, także został zasuspendowany (NISS, 2019).

Wydarzeniom związanym z procesem uzyskania autokefalii rząd starał się nadać rangę uroczystości religijno-państwowych. Sobór zjednoczeniowy odbywał się w Soborze Sofijskim w Kijowie - symbolicznym i „najczcigodniejszym miejscu Ukrainy” (Olszański, 2018b, s. 2). Była tu pierwotnie siedziba metropolitów kijowskich i miejsce pochówku wielkich książąt, z miejscem tym wiąże się historia UAPC. Przed świątynią trwał liczny wiec patriotyczny, który prowadził minister kultury J. Nyszczuk. Ze sceny przemawiali politycy, znani religioznawcy (np. L. Fyłypowycz, I. Kozłowski - uwolniony z niewoli separatystów w Donbasie), wojskowi, artyści, działacze religijni. Wieczorem na scenie pojawił się metropolita Epifaniusz w asyście prezydenta i przewodniczącego parlamentu. Prezentacja nowo wybranego zwierzchnika PCU przez głowę państwa w pewnym sensie przypominała średniowieczną inwestyturę (Olszański, 2018b, s. 3).

Spełnienie warunków wstępnych otworzyło drogę do otrzymania przez PCU autokefalii. Główne uroczystości odbyły się na Fanarze w Stambule. 5 stycznia 2019 r. patriarcha Bartłomiej I podpisał tomos, który nazajutrz został wręczony 
zwierzchnikowi PCU Epifaniuszowi w trakcie wspólnie celebrowanej liturgii. Na uroczystościach byli obecni liczni dostojnicy kościelni i państwowi z Ukrainy, reprezentanci diaspory ukraińskiej. 7 stycznia tomos został zaprezentowany w Soborze Sofijskim w Kijowie. Przyszły go obejrzeć rzesze Ukraińców. Media ukraińskie transmitowały na żywo te wydarzenia. W Kijowie kolportowano ulotki i gazetki pt. „Tomos dla Ukrainy” ze zdjęciem prezydenta z patriarchą Bartłomiejem i metropolitą Epifaniuszem. W kolejnych miesiącach tomos był prezentowany $\mathrm{w}$ innych miastach Ukrainy, $\mathrm{z}$ udziałem prezydenta Poroszenki. Politycy z obozu władzy, w tym premier Ukrainy W. Hrojsman i minister obrony S. Połtorak, podkreślali historyczne znaczenie wydarzenia. Rząd zadbał, by ten ważny sukces znalazł się w programach nauczania szkół (Shchodo vysvitlennya, 2019).

\section{IMPLIKACJE POLITYCZNE I PERCEPCJA SPOŁECZNA NOWEGO KOŚCIOŁA}

Zważając na dotychczasowe tempo starań o autokefalię, przyśpieszenie procesu w 2018 r. dla części obserwatorów było zaskoczeniem. Badania Fundacji Demokratyczne Inicjatywy wśród ekspertów ukraińskich we wrześniu 2018 r. wykazały, że zdecydowana większość z nich postrzegała te zabiegi przede wszystkim jako problem polityczny lub geopolityczny. Mimo to prawie wszyscy pozytywnie oceniali wkład władz ukraińskich. Dominowało przekonanie, że organy władzy zdołają zapewnić pokojowy przebieg przechodzenia jednostek UPC do PCU (DIF, 2018).

Prezydent Poroszenko wykorzystał swój aktywny udział w tworzeniu PCU i uzyskaniu autokefalii w kampanii o reelekcję. Właśnie zbliżający się termin wyborów (31 marca 2019 r.) determinował pośpiech w finalizacji projektu. Tomos był atutem, którego podważenie było ryzykiem dla konkurentów z obozu patriotycznego. Główna rywalka Poroszenki J. Tymoszenko, przewodnicząca partii Ojczyzna, wchodzącej do lutego 2016 r. do koalicji rządzącej, i do momentu ogłoszenia startu w wyborach W. Zełeńskiego liderka sondaży, poparła uchwały soboru zjednoczeniowego (Olszański, 2018b, s. 4). Inny konkurent i dawny koalicjant - lider Radykalnej Partii Oleg Laszko, który krytykował rywala, m.in. twierdząc, że prawosławni na Ukrainie to nie tylko elektorat P. Poroszenki, osiągnął niski wynik wyborczy (ok. 5,5\%). W programie wyborczym Poroszenki uzyskanie autokefalii PCU określono „aktem duchowej niezależności Ukrainy” 
(Pietnoczka, 2019, 197). Osiągnięcie to eksponowała w kampanii parlamentarnej 2019 r. Europejska Solidarność, sukcesorka Bloku Petra Poroszenki. Z kolei prorosyjska Opozycyjna Platforma - „Za Życie” w obu kampaniach obiecała nieingerowanie państwa w sprawy religijne. Pozostałe partie, w tym zwycięska Sługa Narodu, nie odniosły się bezpośrednio do tematu, wzmiankując tylko o potrzebie duchowego rozwoju narodu (Peredvyborni, 2019).

Mimo że sprawa autokefalii nie przełożyła się na sukces wyborczy P. Poroszenki, to odegrana przezeń rola w procesie jej uzyskania stwarzała możliwość powrotu „do wielkiej polityki” (Olszański 2018b, s. 4). Zważając na to, że jego ugrupowanie Europejska Solidarność weszło do nowego parlamentu w 2019 r., a ponad połowa jej elektoratu (52\%) utożsamiała się z PCU (Razumkov Centre, 2020), element ten nadal ma w sobie potencjał mobilizacyjny.

W ocenie niektórych obserwatorów autokefalia PCU była jednym z ważniejszych wydarzeń w dziejach Ukrainy po 1991 r. (Andrusieczko, 2019). Jej pozytywna ocena jest łączona $\mathrm{z}$ interesami polityki bezpieczeństwa Ukrainy (NISS, 2019). Rozwój PCU ma znaczenie dla kształtowania tożsamości narodu ukraińskiego, która będzie definiować wizję przyszłości państwa. Kościół ten może odegrać pewną rolę we wzmocnieniu międzynarodowej pozycji Ukrainy, gdy uzyska członkostwo w międzynarodowych organizacjach religijnych i innych gremiach światowych. Wówczas będzie w stanie reprezentować interesy Ukrainy samodzielnie. Dotychczas paradoksalnie funkcję tę pełniła RPC ze względu na zależność jurysdykcyjną UPC, która jako jedyna była uznawana za kanoniczną (Piechowska, 2020). PCU może zatem stać się narzędziem ukraińskiej dyplomacji publicznej, broniąc pozytywnego wizerunku Ukrainy przed atakami propagandy rosyjskiej (NISS, 2019).

Z perspektywy interesów bezpieczeństwa Ukrainy najistotniejszym skutkiem zdobycia autokefalii PCU było jednak zainicjowanie procesu ograniczania oddziaływania propagandy rosyjskiej na społeczeństwo ukraińskie poprzez kanały kościelne (Kowalczyk, 2020, s. 12). Utrwalenie efektu zależeć będzie od tempa i skali rozwoju struktury PCU. Na początku 2020 r. do PCU przeszło ok. 550 parafii UPC. PCU miała łącznie ok. 7 tys. parafii, a w UPC pozostało ok. 12 tys. (Piechowska, 2020). Tempo przejść z UPC do PCU okazało się jednak niższe, niż zakładano. Pod koniec roku PCU liczyła 44 diecezje, ponad 7 tys. parafii, 80 klasztorów, 9 seminariów, 4,5 tys. duchownych, w tym 60 biskupów (Dopovid', 2020).

Powstanie PCU nie zakończyło zatem całkowicie rozłamu w prawosławiu na Ukrainie, co niesie ze sobą pewne konsekwencje dla bezpieczeństwa wewnętrz- 
nego. Rywalizacja dwóch wrogo nastawionych do siebie grup kościelnych wiąże się z ryzykiem destabilizacji stosunków społecznych i instrumentalizacji tej sytuacji przez siły polityczne i organizacje nacjonalistyczne, utożsamiające się z konkretnym Kościołem. Zgodnie z prognozami (np. Olszański, 2018b, s. 5) źródłem konfliktów lokalnych jest zwłaszcza kwestia prawa użytkowania świątyń i innego mienia organizacji religijnych ${ }^{3}$. Fakt, że cześć budowli sakralnych, zwłaszcza wzniesionych do 1991 r., nadal stanowi własność państwa, utrudnia mu zachowanie całkowitej neutralności i daje pole do wywierania nacisków. To $\mathrm{z}$ kolei rodzi oskarżenia o łamanie zasady rozdziału Kościoła i państwa. Punktami zapalnymi pozostają dwa najważniejsze ośrodki duchowości prawosławnej - Ławra Poczajowska i Kijowsko-Peczerska, nastawione promoskiewsko i wywierające duży wpływ na postawy społeczne i polityczne swych wiernych.

Spory powstają także wokół kwestii prawnych na skutek przyjęcia ustawy z 20 grudnia 2018 r., która zmuszała UPC do zmiany nazwy na RPC na Ukrainie (Zakon, 2018), oraz ustawy z 17 stycznia 2019 r., która regulowała procedurę zmiany przynależności organizacji religijnych (Zakon, 2019). Opozycja zaskarżyła oba akty prawne do Sądu Konstytucyjnego, który odmówił wszczęcia postępowania w przypadku tej drugiej.

Dodatkowo kłopoty były pochodną zmiany obozu władzy w 2019 r. Został zreorganizowany główny organ państwowy, który rejestrował statuty kurii, klasztorów, bractw religijnych i misji. Zamiast Państwowego Departamentu ds. Narodowości i Religii w Ministerstwie Kultury i Polityki Informacyjnej powstała Państwowa Służba Ukrainy ds. Polityki Etnicznej i Wolności Sumienia, która miała nową siedzibę i kierownictwo. Sytuacja poprawiła się pod koniec 2020 r. Większe problemy pojawiły się na szczeblu lokalnym, gdy np. obwodowa administracja państwowa celowo przeciągała rejestrację statutu parafii, która chciała przejść do PCU. Zwierzchnik tego Kościoła ponadto wskazywał, że „niemal zawsze styka się ona z presją informacyjną, fizyczną i prawną ze strony Patriarchatu Moskiewskiego na Ukrainie oraz sojuszniczych z nim struktur politycznych i biznesowych, wnioskodawca jest pozywany do sądu, jest blokowany dostęp do mienia, odbywa się zastraszanie i presja wobec aktywnych parafian" (Dopovid', 2020).

3 Są to m.in. gminy religijne (parafie), zarządy (kurie biskupie), klasztory, bractwa religijne, misje, szkoły duchowne, które mają osobowość prawną i z nimi państwo zawiera umowy w sprawie użytkowania świątyń lub innej własności. Kościoły jako całość nie są podmiotami prawa na Ukrainie. 
Obstrukcja ze strony urzędników wynika po części z niejednoznacznego stanowiska centralnych organów. Dla obecnego obozu władzy, w tym prezydenta W. Zełenskiego, utrwalenie autokefalii PCU nie ma priorytetowego znaczenia. Nie dziwi to, zważając, że wśród elektoratu rządzącej Sługi Narodu jest najwyższy odsetek „po prostu prawosławnych” (35\%) (Konfesiyna, 2020). Prezydent uważa, że państwo nie powinno ingerować w sprawy religijne, gdyż te dzielą Ukraińców, mimo że ponad ich połowa uznawała tomos za czynnik łączący społeczeństwo (Piechowska, 2020). Stąd głowa państwa działa „wielowektorowo”. Przykładowo W. Zełeński nie pojawił się osobiście na obchodach pierwszej rocznicy intronizacji metropolity Epifaniusza, ale zaprosił jesienią 2020 r. patriarchę Bartłomieja I na Ukrainę. Uchylił się jednak od deklaracji przekazania ławry w Kijowie PCU, w odpowiedzi na petycję społeczną, tłumacząc, że sprawa leży w gestii rządu (Prypynyty, 2020). Zastępca szefa Biura Prezydenta S. Trofimow podważał zaś legalność zmiany przynależności kościelnej parafii (Pavlenko, 2020).Z kolei jeden z doradców prezydenta, S. Siwocho, proponował ścisłą współpracę z UPC przy reintegracji niekontrolowanych terenów Donbasu (Piechowska, 2020).

Jak słusznie zauważają analitycy (Kowalczyk, 2020, s. 12), rozwój PCU wymaga dalszego wsparcia politycznego, jak miało to miejsce w przypadku jej utworzenia i uzyskania autokefalii. Niektórzy (Pavlenko, 2020) wprost przyznają, że utrudnianie tego procesu jest nieodpowiedzialne i osłabia bezpieczeństwo państwa. Obecny obóz władzy unika jednak decyzji konfliktogennych, w tym w kwestii ławr. Głośno zgłaszane w debacie publicznej postulaty, by państwo rozwiązało z podmiotami UPC umowy o użytkowanie obiektów sakralnych pod zarzutem nieprzestrzegania przepisów sanitarnych w czasie pandemii Covid-19, nie mają dostatecznych podstaw prawnych. Dostarczają też Rosji argumentów $\mathrm{w}$ wojnie informacyjnej przeciw Ukrainie, budując poprzez wyolbrzymienie dyskryminacji religijnych (zob. MID, 2020) narrację o „państwie upadłym”. RPC i media rosyjskie podsycają też obawy w związku z planowaną w $2021 \mathrm{r}$. wizytą patriarchy Bartłomieja I na Ukrainę. UPC martwi perspektywa zmiany obecnego kierunku polityki wyznaniowej rządu, bo z nowym obozem władzy wiązała wielkie nadzieje. Wspomniane wydarzenie nie musi jednak zapowiadać stałego zwrotu w polityce, choć może mieć znaczenie wizerunkowe dla państwa, gdyż odbyło się w okresie obchodów 30. rocznicy niepodległości Ukrainy. Bojąc się nowej fali rozwoju PCU i zwiększenia presji administracyjnej, wierni i duchowni UPC apelowali do prezydenta o obronę ich praw (Viruyuchi, 2021).

Niewątpliwie rozwój PCU będzie ponadto zależał od uznania przez pozostałe Kościoły autokefaliczne. Proces ten stanowi element otwartego już 
konfliktu między PM i Konstantynopolitańskim o prymat i interesy w świecie prawosławnym. Podważanie przez ten ostatni zasadności dalszego istnienia metropolii kijowskiej UPC (Kowalczyk, 2020, s. 11) zagraża pozycji PM jako najliczniejszego Kościoła autokefalicznego. Parafie UPC stanowiły bowiem ok. 1/3 wszystkich parafii PM, z wysoką liczbą wiernych i dochodów (Olszański, 2018a, 2). Determinacja RPC w utrzymaniu frontu sojuszników jest tym większa (zob. V zashchitu, 2021), iż w ciągu pierwszego roku autokefalię PCU uznały, poza Konstantynopolitańskim, także Patriarchat Aleksandryjski, Kościół Grecji oraz Cypru. Licząc na uznanie ze strony Rumuńskiego Kościoła, PCU w lipcu 2019 r. utworzyła dla ludności rumuńskiej na Bukowinie Wikariat Rumuński jako jednostkę samorządną (Piechowska 2020). Krok ten nie był bez znaczenia też w kontekście gorącej dyskusji wokół praw językowych mniejszości, która była związana z ukraińską reformą oświatową z 2017 r. Proces uznawania PCU przez pozostałe Kościoły z czasem będzie postępował, co może prowadzić do wzrostu samoizolacji RPC i wzmocnienia ośrodka ukraińskiego (Kowalczyk, 2020, ss. 11-12). Przypadek ukraiński budzi nadzieję innych narodów posiadających nieuznawane dziś Kościoły, np. w Macedonii Północnej czy Czarnogórze. Spór o ukraińską autokefalię rzutuje na międzynarodowe stosunki polityczne z konfliktem rosyjsko-ukraińskim w tle. Na przykład poparcie PCU przez amerykańskiego sekretarza stanu M. Pompeo było pretekstem do oskarżeń ze strony dyplomacji rosyjskiej o to, że Stany Zjednoczone wywierają presję na Kościoły autokefaliczne (TASS, 2020).

O popularności PCU w społeczeństwie ukraińskim świadczy fakt, że już rok po utworzeniu i uzyskaniu autokefalii stała się najliczniejszym Kościołem na Ukrainie. W sondażu Centrum Razumkowa ze stycznia 2020 r. przynależność do niego deklarowało 34\% Ukraińców, podczas gdy do UPC - 14\%, a $28 \%$ określiło się jako „po prostu prawosławni”. PCU jest popularna w podobnym stopniu w różnych grupach wiekowych, w przeciwieństwie do UPC, gdzie liczba zwolenników rośnie wraz z ich wiekiem. Pod względem preferencji politycznych najwięcej wiernych UPC to elektorat Platformy Opozycyjnej - „Za Życie” (27\%) (Razumkov Centre, 2020). Utrwalenie pozytywnego wizerunku młodego autokefalicznego Kościoła potwierdza sondaż Międzynarodowego Instytutu Socjologii w Kijowie z lutego 2020 r. Do PCU przychylnie nastawionych było najwięcej ankietowanych (61\%), w porównaniu do pozostałych największych Kościołów. W przekroju regionalnym pozytywny stosunek do PCU deklarowało np. 70\% mieszkańców zachodu, 57\% - Donbasu i 55\% - południa. Na drugiej pozycji 
pod tym względem uplasował się Ukraiński Kościół Greckokatolicki (35\%), a dopiero na trzeciej - UPC (26\%), do której w skali kraju więcej badanych miało negatywny stosunek (28\%) (KIIS, 2020).

\section{PODSUMOWANIE}

Koncepcja autokefalii Kościoła prawosławnego na Ukrainie, sięgająca lat 20. XX w., wróciła do debaty publicznej po uzyskaniu niepodległości Ukrainy. Pomimo poparcia idei przez poszczególnych przywódców politycznych, osiągnięcie szerszego porozumienia politycznego $\mathrm{w}$ tej sprawie okazało się niemożliwe. Brakowało też powszechnego poparcia społecznego, trudne do przezwyciężenia były podziały religijne i związana $\mathrm{z}$ nimi niechęć episkopatu poszczególnych Kościołów. Dążenia udało zrealizować dopiero po Rewolucji Godności, gdy uświadomiono zagrożenia dla państwowości Ukrainy. Stało się to czynnikiem determinującym porewolucyjny obóz władzy do znalezienia konsensusu politycznego i pokonania przeszkód na drodze uzyskania autokefalii przez zjednoczony Kościół ukraiński. Zakończone sukcesem starania o autokefalię łączono ze wzmocnieniem państwowości i pozycji międzynarodowej Ukrainy, oraz tożsamości i jedności narodu, redukcją zagrożeń płynących z zależności od ośrodka religijnego i politycznego w Moskwie, i wykorzystania kanałów kościelnych do propagowania poglądów i postaw antyukraińskich. W tym sensie działania władz ukraińskich korelowały z założeniami porewolucyjnej polityki bezpieczeństwa Ukrainy. Perspektywy rozwoju PCU, pomimo rosnącej popularności w społeczeństwie, będą zależały m.in. od dalszego wsparcia ze strony ukraińskich organów władzy.

\section{BIBLIOGRAFIA:}

Andrusieczko, P. (2019). Prawosławna Cerkiew Ukrainy - między wiara a polityką. Pobrane z: https://outride.rs/pl/prawoslawna-cerkiew-ukrainy-miedzy-wiara-apolityka.

Chervonenko, V. (2018). Prymus do soboru? Za shcho mytropolyta UPTS MP Ilariona ne vypuskayut' $z$ "DNR". Pobrane z: https://www.bbc.com/ukrainian/features-46507264.

DIF (2018). Tomos dlya Ukrayiny - ekspertna dumka. Pobrane z: https://dif.org.ua/en/ article/tomos-dlya-ukraini-ekspertna-dumka.

Dopovid' predstoyatelya na Arkhiyereys'komu Sobori 15 hrudnya 2020 roku (2020). Pobrane z: https://www.pomisna.info/uk/document-post/dopovid-predstoyatelya -na-arhiyerejskomu-sobori-15-grudnya-2020-roku. 
Fert, A. (2020). Tserkovna nezalezhnist' yak istorychna spravedlyvist': istorychni naratyvy navkolo borot'byza Tomos. Pobrane z: https:/uamoderna.com/shafka-dok/czerkovna-nezalezhnist-yak-istorichna-spravedlivist-istorichni-narativi-navkolo -borotbi-za-tomos.

Harbatski, A. (2015). Tożsamość religijna a bezpieczeństwo konfesyjne: współczesne wyzwania (na przykładzie republiki Białoruś). Pogranicze. Studia Społeczne, XXV, $135-150$.

KIIS (2020). Stavlennya do okremykh Tserkov Ukrayiny i ochikuvannya vid diyal'nosti Pravoslavnoyi Tserkvy Ukrayiny: lyutyy 2020 roku. Pobrane z: http://kiis.com. ua/?lang=eng\&cat=reports\&id=921\&page $=1$.

Kowalczyk, J. (2020), Społeczno-polityczne uwarunkowania powstania Kościoła Prawosławnego Ukrainy. Analizy/ Historia. Centrum Europy Wschodniej UMCS, 26.

Kozyrska, A. (2014). Pluralizm wyznaniowy a integracja narodu ukraińskiego po 1991 roku. Toruń: Europejskie Centrum Edukacyjne.

Kozyrska, A. (2018). Wyzwania w sferze wyznaniowej w koncepcji bezpieczeństwa narodowego Ukrainy. Nowa Polityka Wschodnia, 2(17), 7-32.

Maltsev, V. (2016). Zhertva grazhdanskoy voyny. Presledovaniya Ukrainskoy pravoslavnoy tserkvi v khodekonflikta na Ukraine. Moskva: Information Group On Crimes Against The Person.

MID (2020). O situatsii s pravami cheloveka na Ukraine. Doklad Ministerstva inostrannykh Del Rossiyskoj Federatsii. Pobrane z: https://www.mid.ru/ru/web/guest/ foreign_policy/humanitarian_cooperation/-/asset_publisher/bB3NYd16mBFC/ content/id/4474516\#6.

Mironowicz, A. (2007). Zarys dziejów Prawosławia w Europie Środkowo-Wschodniej, Lublin: Europejskie Kolegium Polskich i Ukraińskich Uniwersytetów.

MKIP (2018). Zmitsnennya natsional'noyi yednosti: tomos. Pobrane $\mathrm{z}$ : https://mkip.gov. ua/news/2514.html.

NISS (2017). Analitychna dopovid' do Shchorichnoho Poslannya Prezydenta Ukrayiny do Verkhovnoyi Rady Ukrayiny «Pro vnutrishnye ta zovnishnye stanovyshche Ukrayiny $\checkmark 2017$ rotsi». Kyyiv: NISS.

NISS (2018). Analitychna dopovid' do Shchorichnoho Poslannya Prezydenta Ukrayiny do Verkhovnoyi Rady Ukrayiny "Pro vnutrishnye ta zovnishnye stanovyshche Ukrayiny v 2018 rotsi». Kyyiv: NISS.

NISS (2019). Tomos pro avtokefaliyu ukrayins'koho pravoslav"ya: znachennya i vyklyky. Pobrane z: http://www.niss.gov.ua/doslidzhennya/analitichni-materiali/gumanitarniy-rozvitok/tomos-pro-avtokefaliyu-ukrainskogo.

Oleksiyenko, O. (2014). Relihiyna palitra Ukrayiny. Pobrane z: https://tyzhden.ua/ Society/107903.

Olszański, T.A. (2018a). Konstantynopol: autokefalia dla Ukrainy. Pobrane z: https:// www.osw.waw.pl/pl/publikacje/analizy/2018-10-12/uznanie-przez-patriarchat -ekumeniczny-niezaleznosci-prawoslawnej. 
Olszański, T.A. (2018b). Historyczne zjednoczenie Kościołów prawosławnych Ukrainy. Pobrane z: https://www.osw.waw.pl/pl/publikacje/komentarze-osw/2018-12-17/ historyczne-zjednoczenie-kosciolow-prawoslawnych-ukrainy.

Pavlenko, R. (2020). Dva roky vyklykiv i zrostannya. Pobrane z: https://tyzhden.ua/ Columns/50/249969.

Peredvyborni prohramy politychnykh partiy, kandydaty u narodni deputaty Ukrayiny vid yakykh zareyestrovani u zahal'noderzhavnomu bahatomandatnomu vyborchomu okruzi na pozacherhovykh vyborakhnarodnykh deputativ Ukrayiny 21 lypnya 2019 roku (2019). Uryadovyy kur"yer, 129.

Piechowska, M. (2020). Cerkiew Prawostawna Ukrainy - rok po uzyskaniu autokefalii. Pobrane z: https://www.pism.pl/publikacje/Cerkiew_Prawoslawna_Ukrainy_rok_ po_uzyskaniu_autokefalii.

Pietnoczka, P. (2019). Priorytety programowe kandydatów na urząd prezydenta Ukrainy w 2019 roku. Przeglad Wschodnioeuropejski, 10(2), 193-202.

Poslannya Prezydenta Ukrayiny Poroshenka do Verkhovnoyi Rady Ukrayiny (2018). Pobrane z: https://www.pravda.com.ua/articles/2018/09/20/7192645.

Postanova Verkhovnoyi Rady Ukrayiny „Pro Zvernennya Verkhovnoyi Rady Ukrayiny do Yoho Vsesvyatostivarfolomi Varfolomiya, Arkhiyepyskopa Konstantynopolya i Novoho Rymu, Vselens'koho Patriarkha shchodo nadannya avtokefaliyi Pravoslavniy Tserkvi $v$ Ukrayini" (2016). Pobrane z: http://zakon3.rada.gov.ua/laws/show/1422-19.

Postanova Verkhovnoyi Rady Ukrayiny Pro pidtrymku zvernennya Prezydenta Ukrayiny Dovselens'koho Patriarkha Varfolomiya pro nadannya Tomosu pro avtokefaliyu Pravoslavnoyi Tserkvy v Ukrayini (2018). Pobrane z: https://zakon.rada.gov.ua/ laws/show/2410-19\#Text.

Pravoslavna Tserkva Ukrayiny: shlyakh kriz'viky (Korotkyy istorychnyy narys) (2021). Pobrane z: https://www.pomisna.info/uk/tserkva/istoriya.

Prypynyty vykorystannya Kyyevo-Pechers'koyi lavry Ukrayins'koyu pravoslavnoyu tserkvoyu Moskovs'koho patriarkhatu shlyakhom rozirvannya dohovoru orendy ta peredaty Kyyevo-Pechers'ku lavru u vykorystannya Pravoslavniy Tserkvi Ukrayiny (2020). Pobrane z: https://petition.president.gov.ua/petition/92966.

Razumkov Centre. (2017). Tserkva, suspilstvo, derzhava u protystoyanni vyklykam i zahrozam s'ohodennya. Pobrane z: https://razumkov.org.ua/uploads/article/2017_ Religiya.pdf.

Razumkov Centre. (2020). Konfesiyna ta tserkovna nalezhnist' hromadyan Ukrayiny (sichen' 2020 r. sotsiolohiya). Pobrane z: https://razumkov.org.ua/napriamky/ sotsiologichni-doslidzhennia/konfesiina-ta-tserkovna-nalezhnist-gromadian -ukrainy-sichen-2020 r.

Relihiyna bezpeka/nebezpeka Ukrayiny. Zbirnyk naukovykh prats' i materialiv. (2019). W: A. Kolodnyy (red.). Kyyiv: UAR.

Shapravs 'kyj, S. (2010). Problemy zabezpechennya relihiynoyi bezpeky Ukrayiny ta shlyakhy yikh vyrishennya. Naukovi zapysky. Natsionalnyy universytet «Ostroz'ka akademiya», 2, 167-175. 
Shchodo vysvitlennya pytan'stvorennya Pravoslavnoyi Tserkvy Ukrayiny (2019). Pobrane z: https://osvita.ua/legislation/Ser_osv/63841.

Sobor epyskopiv UPTS $v$ SSHA vydav zayavu v spravi rozhlyadu nadannya Avtokefaliyi UPTS v Ukrayini (2018). Pobrane z: https://ukrainian.voanews.com/a/avtokefaliya -uptse-ukrayina/4364273.html.

Strzelecki, J. (2018). Moskwa - Konstantynopol. Nowa schizma w prawosławiu? Pobrane z: https://www.osw.waw.pl/pl/publikacje/analizy/2018-10-17/zerwanie-stosunkow -pomiedzy-rosyjska-cerkwia-prawoslawna-i.

Svitovyy konhres ukrayintsiv vystupyv na pidtrymku nadannya avtokefaliyi UPTS $v$ Ukrayini (2018). Pobrane z: https://ukrainian.voanews.com/a/svitovyy-konhress -ukrayintsiv-avtokefaliya/4381016.html.

TASS (2020). Glava ukrainskikh raskol'nikov obsudil s Pompeo stanovleniye novoy tserkovnoy struktury. Pobrane $\mathrm{z}$ : https://tass.ru/obschestvo/7655751.

Trojanczuk, J. (2012). Etnofiletyzm $w$ rozłamie cerkiewnym na Ukrainie. W: P. Załęski, E. Breslavskaia, M. Włodarkiewicz (red.). Tożsamości narodowe na obszarze postradzieckim. Między dziedzictwem a tradycja wynaleziona (ss. 191-229). Warszawa: Oficyna Wydawnicza Aspra-JR.

$V$ zashchitu yedinstva Russkoy Pravoslavnoy Tserkvi. Ofitsial'nyy sayt Moskovskogo Patriarkhata (2021). Pobrane z: http://edinstvo.patriarchia.ru.

Viruyuchi Ukrayins'koyi Pravoslavnoyi Tserkvy zvernulysya do Prezydenta Ukrayiny ta Pomisnykh Pravoslavnykh Tserkov (video). (2021). Pobrane z: https://news.church.ua.

Zakon Ukrayiny "Pro vnesennya zminy do statti 12 Zakonu Ukrayiny "Pro svobodu sovisti ta relihiyni orhanizatsiyi. (2018). Pobrane z: https://zakon.rada.gov.ua/laws/ show/2662-19\#Text.

Zakon Ukrayiny «Pro vnesennya zmin do deyakykh zakoniv Ukrayiny shchodo pidlehlosti relihiynykh orhanizatsiy ta protsedury derzhavnoyi reyestratsiyi relihiynykh orhanizatsiy zi statusom yurydychnoyi osoby». (2019). Pobrane z: https://zakon.rada.gov. ua/laws/show/2673-19\#Text.

Zvernennya Svyashchennoho Synodu UPTS do arkhipastyriv, pastyriv, chernetstva ta viryan vid 17 hrudnya 2018 rok. (2018). Pobrane z: https://news.church. ua/2018/12/17/zvernennya-svyashhennogo-sinodu-upc-do-arxipastiriv-pastiriv -chernectva-ta-viryan-vid-17-grudnya. 